\title{
Comparative Study of Damages by Non-performance of Obligations in UNIDROIT Principles, Islamic Jurisprudence and Iranian Laws
}

\author{
Dr. Ghafour Khoeini \\ Kharazmi University Tehran, Associate Professor in Private Law; Department of Law and Political Sciences \\ Kharazmi University, Tehran. , Iran. E-mail:ghkhoeini@khu.ac.ir
}

\section{Ghader Sheneivar*}

Kharazmi University Tehran, Department of Law and Political Sciences, Student of Ph.D. in Jurisprudent and Private Law Department of Law and Political Sciences, Kharazmi University, Tehran , Iran, Email: ghadersheneivar@yahoo.com

Doi:10.5901/mjss.2016.v7n6p133

\section{Abstract}

Principles of international commercial contracts have presented doctrines as certain proposed principles on contracts law by aiming at the unification of private law and have dedicated cases and items in addressing the topic of damages. The mentioned principles have foreseen damages such as principles of loss of profit, damages upon substitute transactions, future harm...A number of those damages have no records of being elaborated in the Islamic Jurisprudence and Iranian laws and the possibility of exercising them in Islamic Laws could be discussed. The possibility of reforming compensation and demanding non-pecuniary compensation emerging from breach of contract are among the topics found in the Institute's principles; and, are proposed to be exercised in the Iranian laws as well.

Keywords: Principles of the Institute, Non-pecuniary Damages, Compensation, Loss of Profit Damages, Future Harm.

\section{Introduction}

Performing the obligations emerging from the contract is the purpose of forming the contracts. The parties do not solely seek forming contracts; they rather aim at performing the obligations. Performing the obligations created by contracts is a desirable object; nevertheless, there is always a possibility that in some cases one of the parties to the contract withdraw or show negligence in performing the obligations which in turn would cause damages to the other party. Different legal systems do not deal with compensating the damages caused by breaching contract obligations in the same manner. In some systems, the concerned damages have limited range while in some other systems they cover a larger scope. The UNIDROIT ${ }^{1}$ Principles are a series of principles proposed by the Institute for Unification of Private Law. The mentioned principles cover different topics in various sections such as formation and validity of contracts, performance of contracts, damages, harms, and ....Damages caused by breach of contract is one of the important parts of the Institute's Principle. Studying the Principles of the Institute for the Unification of Private Law on the international commercial contracts is important and contains many advantages: The principles of the Institute cover concepts which are found in many legal systems; of course, the principles of the Institute are not mere reflection of common and joint concepts of different legal systems; they are rather ideals (Gotanda, 2008, P.109). The mentioned principles cover the most recent ideas on contracts law. The International Court of Arbitration attributes to those principles in settling the claims. ${ }^{2}$ In this paper, the Principles of International Commerce Contracts are referred to briefly as "Institute's Principle".

Studying the Institute's Principle in the topic of damage poses some questions: What place does Pecuniary Damage possess in the Islamic Jurisprudence and Iranian laws"? Does the damage predictability is a requisite in Iran serve as one of the terms and conditions in damage compensation".

\footnotetext{
1 Institute for the Unification of Private Law.

${ }^{2}$ An example of attribution to the principles of the Institute could be found in the case of an American Company versus Iranian Air Force which was heard at the International Chamber of Commerce. In 1977, the Iranian Air Force concluded a contract with an American company. When the dispute rose, the parties agreed to refer the dispute to the general principles of international law and commercial customs and practices. The Chamber of Commerce in its award number 7365 attributed to some of the principles of the Institute on the matter of damage (7-4-9). (Bonel, 2009, P. 328).
} 
The research methodology is descriptive, defining, assessment and literature review. This research has been prepared through reviewing papers and law books in English at the database. The author has reviewed the written materials about the subject, the jurisprudential (Figh) books and law books in English (judiciary procedures, the opinions of jurists, general principles of law) and has presented suggestions on the subject of research. In fact, this research studies the existing status of legal regulations, makes an orderly and systematic description of them, studies their characteristics, properties, nature, processes and procedures and analyzes the relationship between the variables. The research methodology of the paper is based on defining the differences, similarities or common aspects, analysis and evaluation.

\section{Place of Damage in the Principles of the Institute}

Chapter four of principles of the Institute (items 7-4-1 to 7-4-13) contains cases under the topic of "damages". Those principles contain 13 articles that address the issue of Damage. There are articles in the principles of the institute in describing damages that could be demanded along with their different types; and there are other articles that have defined damage compensation methods.

\subsection{Recognizing Damage in the Principles of the Institute}

Damage is not defined in the principles of Institute and the authors of Institute's principle have recognized "any physical injuries with mental pressure and stress", "indemnity caused by loss of chance", "indemnity caused by being deprived from profit"...as attributes to damage. Clause A of Article 7-4-2 rules the mentioned damage to be demandable if caused by not performance. It must be admitted by "not performance" it means not performing the contract obligations in general sense. Cases such as defected and incomplete performance of obligation, delay in performing the obligations and performing obligations in undesirable manner are all included in the category of "not performance" term. In the Principles of the Institute, there are some cases which are considered as damages. Among them, one may recall the damages emerging from [not] negotiation in good faith (articles 2-1-15), damages caused by [not] keeping confidentiality in negotiations (article 2-1-16) and... The matter which is concerned here is the damage caused by failure to comply. It should be mentioned the scope of damages that have the capability of demand are similar to the damages caused by loss of profit; however, some damages based on the principles of the Institute could be claimed; such as the damage of loss of profit caused by breach in contract obligations. The damages that could be claimed in Vienna Convention do not include damages caused by death and damages to persons (article 5 of the Convention). On the other hand, both damages mentioned above could be demanded in accordance with the principles of the Institute; and this is one of the differences between the Vienna Convention and the Principles of the Institute (Gotanda, 2007, P 62). One of the authors believes principles of the Institute in the topic of damage have not differentiated between the damages caused by breach in contract obligations (contract liability) and damages caused by civil liability. In some instances, damages are considered as damages caused by breach of obligations, which, we call them as damages in the category of civil liability. (Perillo, 1994, P. 312).

\subsection{Types of damage in the principles of the Institute}

The damages included in the principles of the Institute can be classified as per different attributes:

A- As per damages that are due to performance of obligations: First- Damages that are due to the performance of principles of contract obligations such as damages caused by not performing the obligation, damages caused by delay in the performance of obligations; two- secondary damages caused by not performing the obligations such as non-pecuniary damages caused by incomplete and defected performance of obligations, damages caused by loss of profit, damages caused by loss of a chance or opportunity.

B- As per the time of damages: First, the present damage: This damage includes damages which are incurred by the obligee, second- future damages: damages which are incurred by the obligee due to the defendant's Failure in complying with the probability of definite future occurrence.

C- As per the type of damage: First- financial damages: It means financial and economic damages which have been occurred or will occur by the oblige due to nonperformance of his/its obligation. Second: non-pecuniary damages: It means pain and suffering occurred to the harmed party (obligee) due to breach in performing the obligations. 


\section{Attributes of Damages by Breach in Contract in the Institute's Principles}

The philosophy of determining damages in the claims related to failure to comply does not aim at compensating damages to the harmed party (the obligee). The Principles of the Institute, by considering the mentioned aim have considered some cases as damages caused by non-performance of contract obligations. Studying the attributes of damage in the Institute's Principles is important in the sense of the extent the mentioned principles has fulfilled the mentioned duty by regarding some cases as damage. In the Institute's Principles, topics such as non-pecuniary damage (physical damages), damages caused by loss of profit, the future harm, damages caused by loss of a chance (opportunity) and...

\subsection{Non-financial damages (non-pecuniary damages)}

In clause two article 7-4-2 it has been specified: "The mentioned damage could be of no financial nature; as for example, might include physical damage or mental stress and pressure." In the definition of non-pecuniary damage 3 it is stated: This set of damages or harms that do not contain financial value and can not be separated from the identity that contains values (Chengwei, 2008, P. 354). Some believe those damages exercisable on the contracts formed between famous athletes, artists and consultants or advisors that work in the organizations or companies (International Institute of Unification of Private Law, 2008, P. 231). The mentioned damages also include cases such as loss or disorder in the commercial fame or change in the commerce conditions as well (Dessemontet, 2002, P. 21). Demanding pecuniary damages face two basic challenges: A- Proof of non-pecuniary damages, B- The amount of pecuniary damage. The mentioned challenges shall not lead to non-deserving of the obligee in claiming the damage. Therefore; it could be accepted the harmed is obligated to prove the damages incurred to him/it; and, determining the amount of damage incurred is the responsibility of the judge or the arbitrator (Bales, 2005, P. 235). In addition, one must note any mental pressure or stress which is caused by breach of contract will not deserve the harmed party to claim the damages; rather, it covers merely that class of damages which in the viewpoints of the parties, the breach of contract has caused mental pressure, stress or hopelessness (Anson, 1998, P. 561). In some cases (such as defamation and jeopardizing business good name), the court can require the defendant to publish official apology in widely circulated dailies (Chengwei, 2008, P. 354).

\subsection{Future harm}

In clause One article 7-4-3, it has been stated, "Legally, the damage is merely considered for a harm including future harm which is determined in a conventional and reasonable degree of finality." According to the mentioned article, the future harm could be demanded when customarily there will be the probability of their occurrence in future. In calculating the mentioned damages, their suitability and the probability of their occurrence are evaluated and assessed accordingly.

\subsection{Damages caused by loss of the chance and opportunity}

According to the regulations of the Principles of Institute, loss of opportunity and use will make the harmed deserved in claiming the damage. Of course, in claiming the mentioned damage, the probability of its occurrence in future is evaluated. If it is not possible to determine the amount of damage, determining it will be put in hand of the arbitrator or the judge. For example, person $A$ who is invited to bid in a tender for building an airport delivers a folder to person $B$ (Express Post) to hand it over to the tenderer on due date. The "B" party delivers the folder after the expiry of bidding deadline and consequently, the bid of " $\mathrm{A}$ " is rejected. The amount of damage incurred to A is assessed proportionally to the degree of its [chance of] success in the tender and comparing it with other bids submitted to the tender (International Institute for the Unification of Private Law, 2004, P. 234).

Claiming the mentioned damage faces two serious challenges: first, occurrence of the damage or capability of its occurrence: The mentioned term is the main condition in claiming the damage; for, it is not possible to sentence the oblige to compensate the damages which have not taken place and/or might never occur. Second- The scope and range of damages demandable: There are discussions on the range of damages that could be claimed. However, as a rule, one must admit the mentioned damage includes physical and financial damages (the damage incurred by the applicant

\footnotetext{
${ }^{3}$ One shall not imply non-pecuniary damage is an innovation of Principles of the Institute. In English Law, this damage is classified as "injury to economic position", harming the economic situation and it means damages or harms which are incurred by the obligee by the failure due to failure to comply in part of the obliged (Peel, 1995, P.842).
} 
because of not taking part in the bid) and the non-pecuniary damage [damages to the fame and good standing] (Chegwei, 2008, P. 378). Since claiming the damage caused by loss of chance and opportunity is completely probable, courts consider the anticipated profits in demanding the mentioned damages; therefore, if the transportation forwarder delays in the delivery of the cargo, he will be responsible for compensating damages on the profits of those contracts the other party could gain (Peel, 1995, P. 861).

As an example, a case was filed in Costa Rica's Arbitration Court in 2001. According to the case, a French company had concluded a joint investment contract with the Costa Rican's company. The French Company had undertaken to perform construction in civil development and reconstruction of equipment and scaffolds for ten years. The French Company unilaterally refrained from the fulfillment of contract obligations reasoning that the Costa Rican company was unable to define the process of construction and performing the project. The Costa Rican Company files a petition versus the French Company in the Court of Arbitration. The Costa Rica Arbitration Court, after examining the contents of the file and attention in the obligations of the French Company ruled that the French Company had breached its obligations of good faith and performing the participation project. Therefore, according to the Principles of the Institute, it [the French Company] was found guilty and was sentenced to compensate the loss of chance (opportunity). However, on the damage of loss of profit, the court rules on no right for the claimant due to undetermined aspect of that demand (Vargas, 2006, P. 181).

\subsection{Loss of Profit Damage}

According to clause one of article 7-4-2- the damage caused by loss of profit could be demanded. The damage of loss of profit has been meant as : Not acquiring profit as a result breach in contract obligations.(Collin, 2004, P. 185). On the mentioned damage it has been said that it covers any profits the obligee [the harmed party] has been deprived of them as a result of non-performance of the obligations by the oblige and it is always undefined (The International Institute for the Unification of Private Law. 2008, P. 229). Of course, the loss of profit damage ordinarily includes the usual and customary profits which the obligee has lost due to breach of contract rather than the extraordinary benefits.

\subsection{The damages upon substitute transactions}

Performing substitute transaction causes the counter party's deserve to [be compensated for] damages caused by the concerned transaction. To elaborate, it means, if the oblige withdraws from performing its obligations and to compensate the mentioned damage, the obligee is forced to perform another transaction within a reasonable time, the obligee can demand the difference between the contract value with the substitute transaction and any other damage (article 7-4-5, Principles of the Institute). For example, a seller sells a good to a customer, after that, it sells the object of transaction (the good) to another (second customer). If the second customer within a reasonable (customary) time purchases the good from another supplier, he can demand the damage caused by the substitute transaction (the difference of the price of the initial transaction with the first buyer; and the price of the transaction with the second buyer). In another example, if the seller after its first purchase faces failure to comply in part of the customer and is forced to sell the good to the second customer, he can demand the damage originated from the difference. The basis of demanding the mentioned damage is the unconventional act of the seller in the failure to comply, and the second transaction of the customer (re-purchase) or the unconventional act of the customer in failure to comply and the second transaction of the seller (re-sale).

In calculation of the difference, the market rate is not accounted for it. The demand of the mentioned difference has been excluded in two cases: first- in a hypothesis when the attempt of the seller or buyer in re-selling or re-buying is carried out beyond the conventional time: For example, their act is not done out of pre-judgment; second- in the assumption, when the price of second transaction (the re-purchase or re-sale rate) is significantly higher in comparison with the second transaction (Chengwei, 2008, Pp 400-420).

\subsection{Damages upon Current value (the damage caused by the difference between the current amount and the contract} rate)

There is the possibility the oblige refrains from fulfilling its obligations and causes damages to the obligee; and the obligee, too, in turn withdraws from performing a substitute transaction. In this situation, the obligee can demand the difference between contract rate and current rate on the date of failure to comply [damages upon current price] (the termination date of contract) as well as any other damages. 


\subsection{The damage caused by money interest and non-monetary obligations}

Articles 7-4-9 and 7-4-10 of the Principles of the Institute have introduced damages under the topic of damages emerging from money interests and non-monetary obligations. The mentioned damages include damages in delay in payment and delay in performing obligations which are accounted for the oblige. The effective date in calculating damages in financial obligations is the commencement of the payment date and in the non-financial obligations, the commencement starts on the time of nonperformance.

\section{The Conditions of Damage Realizations and the Rules of Its Demand Clause One: Conditions of Damage Realization}

According to the principles of the Institute, there are certain conditions required for the realization of the damage. These conditions include: A-Failure to comply by the oblige, B- Occurrence of damage and the capability to predict it, C- The causal relationship between failure to comply and the damage.

\subsection{Non-performance of obligation}

In the Institute's Principles, non-performance of obligations is considered in general term and covers cases such as delay in performing the transaction, unsuitable performance of the obligation and the performance of banned actions. Failure to comply does not contain a particular, certain and unique concept; it includes the same concept which has been accepted in the contracts laws of many countries; and it means the breach of contract obligations.

\subsection{The occurrence and predictability of the damage}

The mere non-performance of obligations does not justify the obligee to claim the damage compensation, rather, it is the occurrence and predictability of the damage which is among the conditions the proof of which is necessary.

\subsubsection{Occurrence of damage}

According to the regulations of the Institute's Principles, damage can be demanded in two cases: First, the damage which has been realized, second- damages which with high probability will be realized. The harmed party (obligee) is obligated to prove the occurrence of the harm. The mentioned condition is not among the certain conditions of the Institute's principles; rather, it is among conditions which are present in all legal systems. The Principles of the Institute considers the future harm or the harms that will be realized in the future. The Principles of the Institute considers the degree and probability of its occurrence in future. Article 7-4-3- emphasizes on "finality of the damage" as a requisite of damage occurrence or its realization.

\subsubsection{Predictability of the damage}

One shall not assume the absence of non performance of contract obligation would justify the obligee to claim any damage compensation; as the harmed party can only claim compensation for the damages which could be predicted. The regulations of the Institute have considered both criteria of type and personal aspects (Bales, 2005, P. 235). In another word, the oblige is responsible on breaching the class of damages it assumed to be incurred by the obligee on the date of breaching the contract performance (personal criteria); or, the damages he could reasonably and customarily predict might occur (type criteria). Of course, on the topic of predictability of the harm, one shall refer to the type of harm as well. The mentioned term has a relative concept which could be interpreted depending on the type of the claim (Chengwei, 2008, P 375). ${ }^{4}$

\footnotetext{
${ }^{4}$ In the British law too, the claimant can claim only that part of the damages which are reasonably caused by the non- performance of the obligations as per the mental data of the parties to the contract. Therefore, if the breach of defendant (oblige)'s obligations caused deprivation of the claimant from a certain and unique benefit/ profit, claiming that certain damage will not be possible (Beale, 2004, Pp.1494-1495, Peel, 1995, P. 813). Article 150 of the French Civil Law too has emphasized o the necessity of predictability of damages. In German, ,Swiss and the Netherlands Law; too, instead of predictability of the damage, the Doctrine of Sufficiency of Causality has been used (Elgar, 2006, P. 263)
} 


\subsection{The occurrence of damage shall be caused by non performance}

One of the conditions of damage realization is the existence of causality relations between the damage and non performance of the obligation as such that the damage incurred by the obligee is directly caused by non performance of the obligation, the failure of the oblige in reducing the damage amount will cause no liability or responsibility (clause one article 4-7-8). In addition, if it is known the oblige has already spent some expenses to reduce the amount of damage, helit will deserve its receipt (clause two, article 7-4-8). The interference of the oblige in the occurrence of the damage, in a type that part of the damages incurred is caused by his act or relinquishing the act. The amount of damage is reduced by considering these factors (article 7-4-7) and causes the share of the oblige and obligee in damage occurrence (Bales 2005, P. 237). The regulations of the Principles of the Institute have merely considered the "conventional behavior of the harmed party [obligee]" in reducing the amount of damage without setting the criteria of "conditions and situation". The message of the above-mentioned regulation is that from the economic point view, increase in damages which could have been reduced by the actions of the harmed party is unreasonable and the harmed party is excused for that part [of the damage] (Fontaine, 2006, P 205).

\section{Regulations of Method of Damage Compensation}

The Principles of the Institute have used certain regulations on the procedures of damage compensation that include: The necessity of Principles of Full compensation, the possibility of damage claims, adopting other procedures and the necessity of payment of damage all at once.

\subsection{The necessity of Full Compensation of Damage}

There is no doubt in the fact no harm should remain uncompensated. The Principles of the Institute do not emphasize on the necessity of compensating the damages rather, it speaks of the necessity of full compensation of the damage in a way that the harm and loss compensation lead to the restoration of the harmed party's situation rather than serving as an instrument for gaining profit. The possibility of reforming (modifying) the obligations amount and reducing its amount (article 7-4-13) verify this principle that compensating the damages of the harmed party is possible in some extent which would compensate its entire damages; and the damage compensation shall not cause an unjust gain. In claiming full compensation in principles of the Institute, there are a number of exclusions and exceptions:

A- In the assumption where the (harming party) oblige did not have good faith in performing obligations. In this state, the oblige personally undertakes a part and a role in non-performance and reduces the responsibility of the harmed person (article 7-4-7) and/or does not take necessary actions for lowering the loss (article 7-4-8).

B- The condition of predictability of the damage lowers the range of damages that could be demanded by the harmed party. It is true the entire damages of the harmed party shall be compensated. Based on this, some believe the principle (the doctrine of the requisite of full compensation) can not execute contract justice (Sica, 2006, Pp17-18).

\subsection{The possibility of demanding damage and adopting other procedures}

One shall not assume the harmed party can only demand the damages caused by failure to comply, rather, along with claiming those damages, he can demand other damages and even forcing the oblige to perform obligation as well. In article 7-4-1 of the Principles of the Institute, it has been stipulated: "Any non-performance of obligation entitles the harmed party to claim damage compensation exclusively or along with other procedures...". Demanding one of the damages does not conflict with the possibility of demanding other damages; for example, the harmed party can claim the loss of profit damage along with non-pecuniary damages.

\subsection{The necessity of payment of damage in whole}

Clause one article 7-4-11 expresses a general principle in which basis, the court or the arbitrator is obligated to pay the damage compensation at once. Nevertheless, the court or arbitrator can order for payment in the cases as the "nature of damage" requires. 


\subsection{Obligations amount}

According to article 7-4-13 of the Principles of the Institute, the parties to the contract by mutual agreement can predict an amount as the obligations security amount for the violation of the oblige from performing the obligations. The obligee's liability to receive the mentioned amount refers to the governance of will. Despite it, the mentioned obligation security amount has two characteristics: First, the harmed party deserves the receipt of the amount in the contract even if the mentioned amount exceeds actual damage. Second- If the amount of security is much higher than usual amount of the time and place, it can be reduced to a reasonable and conventional amount. ${ }^{5}$

\section{Comparative Study of the Principles of Institute, Islamic Jurisprudence and Iranian Laws}

A comparative study on damage in the Principle of Institute, Islamic jurisprudence and Iranian laws requires explaining the similarities and differentiation aspects as well as their advantages and disadvantages.

\subsection{The similarities and differentiation aspects}

A- In the principles of the Institute, the defected, incomplete and delayed execution with delay means the non performance of obligations and the harmed party will be deserved to receive the damage (article 7-1-1). The same is in Iranian law too (Katouzian, 2008, P. 144). In addition, one of the fundamental principles of the Institute on claiming the damage is the necessity of full compensation of the damage (clause one article 7-42). In Islamic jurisprudence; too, there is rule under the topic of "no loss" according to which, no loss shall be left uncompensated.

B- According to the Institute's Principles, the harmed party in case of non-performance of obligations or its incomplete performance can demand damages caused by delay or non-performance in addition to the original obligations (article 7-4-1). Some justify the delay damage in performing the rules (Zanjani, 2003, P. 213). In Iranian law, there are differences in opinion on the possibility of claiming damage by requiring the performance of the principle of obligations: One of the authorities in this area believes in the impossibility of claiming damage caused by its non-performance along with the damages thereof and believes damage caused by non-performing the obligations substitutes the original obligations and as the original obligation is not fulfilled, its substitute will replace it; and the original and the substitute can not be claimed at the same time (Katouzian, 2006, P. 393). In turn, some jurists are in favor of the possibility of claiming the damage along with the requirement of forcing the fulfillment of the original obligation (Emami, 2000, P. 243, Shahidi, 2003, P. 67).

C- For the future harm too, some authors believe it possible to demand damage compensation as per article 515 of Civil Procedures Code. One of the authors believes the existence of damage is one of the foundations in the realization of damage. In future harm (loss) too, the capacity is the realization of future damage and presently there is no damage the oblige is required to fulfill. Therefore, demanding future damage is not free from defects (Shahidi, 2007, Pp 264-265).

D- On the possibility of claiming the profit loss claim, there is difference in the idea in the Iranian laws: some believe there might be stated in clause 2, article 9 of Civil Procedures Code governs the demand of damages caused by the loss of profit in crimes and in other cases, the provisions of the mentioned text in Civil Procedures Code is exercised. In another word, the principle of impossibility to claim damage (compensation) is due to loss of profit; nevertheless, the possibility of its claims on the crimes has been excluded. However, this reasoning is challenged on the ground that the crime does not have the characteristics which could exclude the claim damage compensation caused by no profit (Ghasemi, 2005, P. 150). In note 2 of article 14 of new Civil Procedures Code it is stipulated: "Profits that can be obtained are only for the cases when the attribute is lost". Some believe claiming damages caused by profit loss; too, is not possible by attention to note 2, article 515 of Civil Procedure Code; for, there is no ground and introduction to the mentioned damages and there is no evidence on gaining it in future either; and, this damage has probable aspect. Therefore, it goes beyond the range of possible damages (Shams 2005, P. 406). Despite this, some contemporary Shiite jurisprudents believe claiming the damages emerging from reinforcing the opportunity due to the possibility of

5 In French Law too, the principles of Institute makes it possible to change the amount of guarantee fund by the governor (article 1152 Civil law of France). The British courts too refrain from exercising the terms of the contract on stipulating the security fund of large amount on non performance of contract obligations (Anson, 1998, P. 587). 
gaining profits: The explanation is if in accordance with strong evidences, the mentioned profits are certain to be gained, the rule will be in favor of security and guaranty fund; however, if the evidences of gaining the mentioned profit is not certain, the rule will be in favor of non guaranty and security amount (Rouhani, 2009, P. 211, Zanjani, 2003, P. 216). In Imami Jurisprudence too, the issue of reinforcing benefits has been discussed as remuneration. In a hypothesis when in the hire [contract] the lessor withdraws from hire delivery and it is not possible to force him to deliver the subject of hire, the lessee can cancel the contract and receive the hired object, or keep the contract and claim the substitute for the lost profit (Fazlollah, 1998, P. 122 and 123). In hiring a person, when the hired person is assigned to perform a certain task for a certain person, the profit will belong to the lessor [employer] and the hired person will not be allowed to do an act which is against the assignment; otherwise, the employer will be authorized to claim the benefits to be paid by the hired and the third person ${ }^{6}$ (Albahrani, 1985, P. 559).

In the Islamic jurisprudence (subject of confiscation), the profits are divided into two exchequer and nonexchequer profits. The famous viewpoint is in favor of claiming the profits of the exchequers and nonexchequers. Attention in the nature of non-exchequer profits indicate those profits are unused profits which are established by the requirement and there is a certain and definite possibility of their usage; however, for some reasons, they are not used. Therefore, the general criteria are the possibility of demanding the probable profit which is formed in future.

E- In the Iranian law, there is no rule on relieving the amount of damage. Nonetheless, since the harmed person is obligated to reduce the amount of damages and his negligence on this matter reduces the liability of the oblige, and in view of the "the rule of action" according to which, the attempt of the obligee in harming his profit will lead to his personal liability, it could be accepted that the rule of relieving the amount of damage is acceptable implicitly both in thelranian laws and Islamic jurisprudence (a group of author, 2008, P. 369).

F- There are differences in views among jurists on the predictability of the damage. Some authors have refrained from providing the fixed rule on this subject (Katouzian, 2008, P. 229). Some believe the damage should be predictable (a group of authors, 2008, P. 385). One of the jurists believe no obligation could be imposed on the oblige beyond the scope of the will of the oblige; for, the liability of the oblige on failure to comply emerges from his will on the time of contract formation and his bound to do so; and it is the oblige that determines the scope of this responsibility (Shahidi, 2007, P. 80).

G- In the principles of the Institute, the general principle is payment of the whole, although, there is the possibility of paying the damages on the installment with respect to "nature of damage". In Iranian law; too, the general principle is paying the debt in full at once; nonetheless, the judge has been authorized to rule on partial payment by considering the debtor's situation rather than the nature of the damage, which is contrary to the principles of the Institute. In addition, in the principles of institute, unlike Iranian laws, the only possibility is payment on installment and there is no possibility of awarding a just deadline.

$\mathrm{H}$ - What discussed in the principles of the Institute under the topic of "Damage for interest" is in compatibility to the damage for delay in payment in the local laws. In fact, the mentioned damage is some kind of damage in delay in payment which is calculated and paid from the date of loss occurrence to the receipt of the judgment amount. In addition, in accordance with article 522 of civil procedures code, order has been awarded for its payment. Some contemporary authorities believe that damage as having usury nature and state its claiming lacks religious justification; and it can not be justified by the money devaluation, loss caused by lowering purchase power and the loss caused by loss of profit from money (Zanjani, 2003, Pp 218-219). Some contemporary jurisprudents are in favor of the possibility of collecting the damage of delay in payment due to money devaluation (Montazeri, 2005, P. 126). One of those jurisprudents believes in demanding the mentioned damage by considering the [Quranic] law of faithful servants are bound to fulfill their promises and the oblige is bound to pay his debt; and the oblige will be guilty in non- payment (Mousavi Bojnouri, 2002, P. 483).

\subsection{Advantages and disadvantages}

Damage and the procedure of collecting it in the Principles of the Institute, Islamic Jurisprudence and Iranian Laws have

6 In Hanafi religious jurisprudent, some believe in the event of breaching obligations specified for the hired person against the employer and performing operations for another person, the employer will be allowed to reduce the fee amount proportionally (Alhaskafi, 2012, P. 583). 
many advantages and disadvantages .

A- As implied in article 230 of Civil Procedures Code, if the guaranty (security) amount is conditioned in the contract, the governor can not decrease the amount stipulated in it. According to alternative two of article 7-413, if the amount in the contract under the topic of the guaranty amount exceeds the conventional and reasonable amount, the judge or arbitrator can decrease that amount to the conventional and reasonable amount. In Imami Sunni Jurisprudence, some believe the guaranty amount as binding term (Montazeri. , 2007, p. 281). What proposed in the Iranian law is reform in guaranty amount: The possibility of reducing the guaranty amount is a step towards bringing the guaranty amount close to the actual amount; particularly in the assumption when the amount of guaranty in comparison to the actual damage is significantly large; and/or in the hypothesis when the oblige performs parts of the contract obligations and refrains from other section.

B- According to clause two of article 7-4-2, physical damage and mental stress have the capacity of compensation claim. Some authorities have withdrawn from providing a general criteria on this subject and believe the response to this is a function of the convention, custom and status of the harmed party (Shahidi, 2007, P. 263). The mentioned damage does not have long record in Islamic jurisprudence. Nevertheless, the possibility of claiming it contrains many justifications: First, in some cases, breach of a contract obligations creates large non-pecuniary damages for a businessman. The mentioned damage in comparison with the financial and physical damages caused by defect is trivial. Second, if it is accepted the requisite of full damage compensation is to compensate the damage in full, there should be no discrimination between non-contract damage and the damage caused by breaching the contract obligations; and as article 1 of the civil liability, the order is awarded to compensate, it can be executed on contract responsibility as well.

\section{Conclusion}

Of the sum of the discussions in the paper, it could be concluded that:

A- In the payment of damages caused by failure to comply, one should not be too excessive or too wasteful and the necessity of maintaining justice in the contract should be duly considered: First- the damage shall be considered in a way that would serve as a preventive factor to stop failure to comply from breaching their obligations, second- No damage should be left uncompensated. The range and scope of damage should be in a way that would cover the entire conventional damages.

B- On the possibility of claiming the damage, one shall consider the probability and degree of its occurrence. Based on this, no general measures can be provided on the damages caused by loss of opportunity, future damages, and loss of profit damage..The criteria that shall be considered is "certainty in occurrence of damage." Based on this, damages could be demanded which occur in high probability and in certain.

C- The possibility of demanding non-pecuniary damages caused by breach in contract obligations and the possibility of reform in the security amount are among positive points of the Institute's principles and it is suggested to exercise them in Iranian law. No test is observed in Jurisprudential texts on the non-pecuniary damages. The Iranian civil law; too, in the issue of damages caused by non performance of contract obligations only suffices the possibility of claiming financial damages and no text is found on the nonpecuniary damages. On the other hand, it is accepted no loss shall be left uncompensated and depression (mental distress) is resulted by breaching parts of damages incurred, one can believe in demanding them. In addition, if it is accepted the philosophy of the damage is restoration of the status of the harmed party to the previous state and compensating the damages occurred, in the cases when the obligations security amount is too high, the judge shall have the authority to modify and reform the mentioned amount.

D- One of the Institute's terms on demanding damage is its predictability necessity. In Islamic jurisprudent, no subject is observed. The Iranian civil law; too, is silenced on this matter; nonetheless, it seems the mentioned condition could be exercised in both Islamic jurisprudence and Iranian laws as well: Fairness requires any person shall conventionally responsive to his own actions and bears no responsibilities on the unpredicted instruments and the damages caused by it. Attention in the nature of the contracts indicate in the preliminary negotiations, the oblige considers the entire probable damages and defects and forms the contract based on that; and as a reasonable person, , does not pay attention to the unpredicted events and damages. Order to compensate the unpredicted damages is contrary to the certain principles of reason and logic. 


\section{References}

A group of Author.(2008). International Purchase Law. Vol. 2. Tehran:Tehran University Press.

Bunnel ,M.J.( 2009). "Principles of the Institute for the Unification of Private Law on the International Commercial Contracts and Coordination of International Purchase Law".Journal of International Law.pp 321-235.

Bales, F \& Hotler. P. ( 2005). "Reviews on the Regulations on Claiming Damage in Vienna Convention, Principles of European Contracts Law, UNIDROIT on the UN International Commercial Contracts (UPICC)". journal of Bar Association.pp229-243.

Emami, S. H. (1990). Civil Law, Vol. 1. (15rd ed.). Tehran: Eslamieh Publication.

Ghasemi, M.(2005). Compensation of Damages on Breaching Contract in the Convention on Contracts for the International Sale of Goods (CISG) in the Laws of Iran, France, Egypt and Lebanon, Legal Journal.pp139-220.

International Institute of Unification of Private Law(2008). Principles of International Commercial Contracts, Tehran: Ganje Danesh.

Katouzian, N. (2008). General Rules of Contracts .( 5rd ed.). Tehran: Enteshar Joint Stock Company.

Katouzian, N.(2006). General Opinions of Obligations.(3rd ed.). Tehran: Mizan Publication.

Montazeri,H.( 2007). Resale Esteftaat. Vol.1 \&Vol. 2.(3rd ed.).Tehran: Sayeh Publication.

Mousavi Bojnourdi. S. M.(2002). Collection of Jurisprudential and Social Papers. Vol. 1. , Tehran: Imam Khomeini Research Institute.

Rouhani, M. (2009). Esteftaat. vol. 6 .(3rd ed.).Qom: Mehr Amirolmomenin Publication.

Shahidi, M.(2007). Effects of Contracts and Obligations. Vol. 3. Tehran: Majd Publication.

Shahidi, M. (2003). Civil Law 3 (Obligations Law). Vol. 3. Tehran: Majd Publication.

Shams, A. (2003). Civil Procedures Code. Vol. 3. Tehran: Majd Publication.

Zanjani, A\& Amid.A. (2003). Causes of Securities (guaranty for fund).(1d ed.).Tehran:Mizanrial Publication.

Albohrani, Y. (1994). Alhadaeq Alnazere Fi Ahkam Aletratol Tahere. vol. 21.(2rd ed.).Beirut: Darolzava.

Alhaskafi, A. A. (2000). Aldarol Mokhtar. Vol. 1, Beirut: Darolkotob Alelmieh.

Alzahili V. M.(2009). Qazaya Alfegh valfekrol Moaser,Vol. 2, Damascus : Dalfekr.

Alsalus, A.A.(2008). Feqholbey Valesisaq Valtatbiqol Moaser.Qatar: Darolsaghafeh Aldoha.

Esmaeel , O\& Jaber .M. (2008). Zemanat Alestesmar Fe Feghol Eslami \& Tatbiqatoha Almoaser.Vol. 1. Jordan: Darolnafas Lelnashr Valtozie.

Fazlollah, S. M. H.(1996). Feghol Ejare Fisharhol Orvatolvosgha. Beirut: Darolmolk.

Anson. W. R. \& Beatson. J. \& Burrows. A. S.\& Cartwright. J.(2010) Anson's law of contract.(27rd ed.). Oxford :Oxford University Press.

Beale.H. (2004)Chitty on Contracts.vol2 .(29rd ed.). London:Sweet Maxwell.

Chengwei,L.(2008). Remedies for Non-performance -Perspectives from CISG,

UNIDROIT Principles and PECL.Are available at: www.jus.uio.no/sisu. (july19,2014).

Collin .P.H.(2004).Dictionary of Law. London :Bloomsbury Publishing PIc.

Dessemontet,F.(2002). Use of the UNIDROIT Principles to Interpret and Supplement Domestic Law, ICC International Court of Arbitration Bulletin, Special Supplement.pp 39-50.

Elgar,J.M.(2006). Elgar Encyclopedia of Comparative Law. Massachusetts: Edward Elgar Publishing.

Fontaine,M\& De Ly,F.(2006). Drafting international contracts: analysis of contract clauses. USA: Transnational Publishers.

Gotanda,J.Y.(2008). Using the UNIDROIT Principles to Fill Gaps in the CISG. Contract Damages Domestic and International Perspectives, Portland: Hart Publishing.

Gotanda. J. Y.(2007). Using the Unidroit Principles to fill gaps in the CISG. http://www.ssrn.com/abstract=917424. (july2,2014).

International Institute for the Unification of Private Law.(2004). Unidroit Principles of International Commercial Contracts. Rome: Unidroit.

Perillo, J. M.(1994),UNIDROIT Principles of International Commercial Contracts. The Black Letter Text and a Review. Fordham L. Rev. Available at: http://ir.lawnet.fordham.edu/flr/vol63/iss2/1. (july18,2014).

Sica,L.C.(2006) "Gap Filling in The CISG :May The UNIDROIT Principles Supplement The GAPS in The Convention? Nordic" Journal of Commercial Law. Nordic Journal of Commercial Law.Are available at: http://heinonline.org. (july17,2014).

Peel.F.(1995)Treitel on the Law of Contract.(9rd ed.). London: Sweet Maxwell.

Vargas,V.P\& Umaña ,D.P(2006). The UNIDROIT Principles of International Commercial Contracts in Costa Rican Arbitral Practice. The. Unif. L. Rev. ns. Are available at: http://heinonline.org. (july7,2014). 